\title{
Problems and Trends in Innovative Transformation of Russian Economy and Infrastructure Development
}

\author{
Dmitry Morkovkin \\ Department of Economic Theory \\ Financial University under the Government \\ of the Russian Federation \\ Moscow, Russia \\ MorkovkinDE@mail.ru
}

\author{
Sergey Shmanev \\ Department of Economic Theory \\ Financial University under the Government of the Russian \\ Federation \\ Moscow, Russia \\ shmanev_s_v@mail.ru
}

\author{
Lyudmila Shmaneva \\ Scientific \& Editorial Publishing Department \\ Moscow University under the Ministry of Internal Affairs of \\ the Russian Federation \\ Moscow, Russia \\ shmaneva_luda@mail.ru
}

\begin{abstract}
The article is devoted to the innovation, transformation, and infrastructural development of the Russian economy in the current state of macroeconomic and geopolitical instability. It analyzes the current situation and identifies problems of the infrastructural complex development in Russia. The main attention is paid to the study of the problem of the lack of effective interaction between the key factors of innovation and technological development: the state, science and corporate sector. There are made suggestions on directions of effective application of mechanisms of priority infrastructure projects creation, particularly, the program methods using public-private partnership.
\end{abstract}

Keywords-economy; innovation; infrastructure; innovative development; public-private partnership

\section{INTRODUCTION}

The Russian economy at modern stage of development is situated in conditions of economic instability: drop in oil prices, absence of external funding, devaluation of ruble, economic sanctions against the Russian Federation. Large infrastructure projects can support Russian economy [1]. For example, large investments in transport infrastructure should be considered as an effective measure of economic recovery. Such projects are often started in instable economic dynamics, or even in crises. Such domestic investing, investments in the development of innovation management institutions, which will enable diversification and reduction of the dependence on extractive industries, are particularly requisite for the Russian economic growth. Therefore, the task of infrastructure development in Russia is prioritised in order to enter the stable economic development.

For decades, the economy of our country has been dependent on exports of oil, gas and other raw materials, being appendage of the developed capitalist countries, and it continues to survive in the conditions of economic sanctions At that, Russia adopted political decision aimed at innovative development of the economics. This requires significant financial resources, usage of more effective control mechanisms, which have the development of an innovative component of the economy as an aim, use recent advances in science and technology and the replication of results of intellectual activity. In these circumstances, it is advisable to use advanced forms of integration of industrial enterprises to enhance the stability of the market conditions of fierce competition, as well as import substitution [2]. Solving these problems will allow the Russian economy to develop more rapidly.

\section{THE PROBLEM OF INNOVATIVE DEVELOPMENT}

Firstly, we need to express the views on the definition of "innovation", because some of the reference documents and scientific papers apply the definition that uses the concept of 'innovation practically limited to the result, a new product, forgetting about investment, firstly, in science, and then in new product's manufacture and project implementation. Invention or novation, the so-called innovative result, is not the innovation yet. Under innovation is understood the process of creation of interrelated species of the novation, organization of production and market place based on consistent funding of the investment process, at all stages of innovative activity [3]. Innovation is materialized result, obtained by investment in creation of the new techniques or the technology, in the new forms of organization of labor production, maintenance, management, etc. Therefore, innovation refers, first of all, to the financial indicators. An innovative activity is a driver of economic development, ensuring efficiency and labor productivity growth 
Innovations concern not only the creation of a new material product, but also perfect management. The process of innovation requires effective management. Since it takes place in a certain sequence and is similar to the flow, it can be applied to logistic management, based on the optimization of logistical principles that target to perform administrative tasks more efficiently than usual control. This refers to the creation of the product of the optimal quantity and quality with a minimum costs of design, manufacture, packaging, and voltage. Therefore, logistic management can be understood as the control of streaming processes, based on optimization (minimization) of costs. Flow control of the creation, distribution and usage of market innovation can be called innovative logistics. Recognizing the need to improve the control of logistic component of management, and in case of promotion of the innovative part, the definition of the "innovative logistics" can be applied [4]

Formation of the innovative industrial policy should be based not only on the innovative development of industrial production (as before), but also on the integrated approach to the creation of entire product supply chain, including the production of supplies, transportation, production and sales. Complex approach allows minimizing costs, solving problems of the inter-sector coordination, sector wide development cooperation with commodity markets. National industrial policy should be mainly aimed at innovative and logistics management, rather than the raw orientation.

Innovation policy's success depends on the ability to anticipate and actively co-work with the development of the innovation process in terms of crisis and imposed sanctions [5]. Since the diffusion period of innovations is approximately 25-30 years until the market arrives the state of maturity, for the growth Russian economy needs to reduce it as a result of the replacement of evolutionary processes from the spasmodic ones. This is possible through the usage of advanced innovative achievements that are already made by other countries.

One of the ways of such jump is to buy manufactory for the production of innovative products based on advanced technologies. Here is not meant the organizational assembly production of competitive products (the profit from the sale of it belongs to foreign companies and is sent abroad). That is why this method is not effective for the recovery of the national economy based on innovation.

In contemporary, buying the manufacture for the production of any of any innovative product allows to bring the economy to the world level in the sector. Moreover, the developed product, its production technology, buildings, equipment are the property of the Russian Federation. The whole profit from the sale of an innovative product stays in Russia and can be directed to the development of this and other innovative production. In this way, it creates a step by which Russian economy becomes globally competitive. Based on the existing advanced level organized the further development of national product on its own technology should be organized [6] [7].

Along with this, it is advisable to study and raise already registered but not usable up to now inventions in Russia, to identify the most effective directions of innovation and to begin the development of the projects of their use and bringing to market. The state should be an initiator in this case, and in the financing there can be implemented publicprivate partnership [8] [9] [10].

At the same time, higher authorities should pay attention to the problem of lack of effective interaction between 3 subjects of innovative-technological development: the state, science and business (corporate sector), called out to generate new fundamental knowledge, which would become the drivers of the new economic development of the state, the basis for the formation of highly diversified structure of Russian innovative economy.

One of the conditions of innovative development is the creation of innovative structures, based on the framework companies and with their support, and which will be an incubus for the small ventures. This implies a broad involvement of the scientific and educational institutions potential. Thus, the creature of new technologies for large enterprises, discovery, testing and introduction of them, consulting services, information and support for the formation of a continuous education system on the basis of training and retraining of highly skilled professionals will be carried out.

\section{THE PROBLEM OF INFRASTRUCTURE DEVELOPMENT OF THE ECONOMY}

One of the priority directions of the state policy is setting up the mechanisms providing development of the commodity markets and formation of the necessary organizational and economic prerequisites for effective competition in the commodity markets. The infrastructure of the commodity markets is an essential step of creation and use of valuable assets, part of a chain of human life. That is why the market infrastructure is primary for sustainable economic growth in Russia [11].

It should be noted that the development of infrastructure in Russia, the formation of market infrastructure investments, as well as the maintenance of the social sphere, are associated with many other problems that need to be identified and addressed. Some of them have structural nature in the Russian economy, but for increasing of the investment attractiveness of the infrastructural projects, these problems must be solved.

One of the problems is the lack of transparency of such important processes as an adoption of public administration of investments in infrastructure solutions, tender mechanisms of public procurement and legislative support of the process. Ensuring transparency and competitiveness of the tender procedures may increase the efficiency of the investments in the Russian infrastructure. Lack of transparency of decisionmaking mechanisms for the implementation of projects is one of the main obstacles, impeding the development of infrastructure in Russia.

At the same time, insufficient guarantees of return on investment are one of the main obstacles to attracting private investment in infrastructure. Corporate sector is ready to 
invest in Russian infrastructure, but it counts on the necessary assistance to the government in achieving the desired level of profitability.

The important issues include the provision of state support to infrastructural projects at the regional level. We gather, regional projects in the current economic conditions should receive funding from the federal budget. The process of obtaining such financing should be preceded by the fulfillment of preconditions ensuring the project's effectiveness, for example, providing methodological assistance to the regions that initiated infrastructure projects. Essential factor which constraints the progress of this process in Russia is the lack of the unified regional infrastructure development strategy [12].

The main sources of financing for infrastructure currently are:

- Federal budget;

- National Welfare Fund (NWF);

- Regional budgets;

- Own and attracted financial resources of natural monopolies (Russian Railways, etc.) and public corporations (Foreign Trade Bank, Autodor etc.);

- Citizens' pension savings invested in the priority projects through pension funds;

- Loans of commercial banks;

- Private investors, including foreign ones;

- Cash flows of infrastructure projects [13].

In the coming years, the share of government spending on infrastructure will be short due to the fall of the state budget revenues. However, this reduction will be partially offset by increased investment from the NWF and by pension funds, which became access to pension savings of citizens. However, in the current state of macroeconomic instability the government should take the lead in investments in infrastructure projects and innovative direction for showing the example of their reliability to corporate sector and involving him in creating of innovative products.

At the global background, Russia has relatively high income and consumption levels, stable low level of unemployment and high level of education, virtually eliminated absolute poverty. However, the low level of infrastructure development negatively affects the quality of life and increases business costs.

At present, the transport infrastructure of Russia lags behind in its development from the advanced foreign countries. About $20 \%$ of the transport infrastructure projects in Russian regions are currently at the stage of delay or frozen. Experts now warn of the adverse effects of such steps: without the development of infrastructure, it is impossible to solve priority objectives of regional policy, which include attracting investment and recovery of economic growth.
Low levels of speed and comfort of passenger trips leads to the fact that people prefer personal cars rather than public transport and stand in many kilometers of traffic jams. Thus, according to sociological studies conducted by the CER in the Moscow metropolitan area, $58 \%$ of Moscow inhabitants drive to Moscow region by private car, $25 \%$ - by railway transport and $11 \%$ - on buses and minibuses [14]. In Greater London, for example, the situation is reversed: not less than $60 \%$ of passengers moving from the center to the suburbs on the public transport.

Transport infrastructure remains one of the most problematic aspects of a socio-economic development of Russia, and requires increased financial and administrative efforts from the state. On the other hand, transport infrastructure investment can bring significant effect to the state and stimulate the economic growth. Budget returns on investment in the transport infrastructure is higher than the investment in the defense sector or oil infrastructure.

\section{CONCLUSION}

To achieve Russia's innovation and technological leadership in the priority real sector at a global scale, we should not reduce the scope of direct participation of the state in the economy, because the complex innovation environment for functioning of the business sector has not been formed yet, there is no strong demand for innovation, pool of Russian huge innovative companies-champions, which requires at this stage direct involvement of the state in the creation and development of innovative infrastructure, stimulating and financing the sector of scientific research in the sphere of the creation of high-tech products.

In our view, in the sphere of realization of the state innovation and industrial policy should the main focus should be concentrated primarily on the direction of the "organizational innovation in public administration" for the managing current adjusted economic policy of the country and improving the efficiency of the state social and economic policy.

\section{REFERENCES}

[1] Russian infrastructure. Investments can not be reduced to increase / Official website of "Gazprombank" (Joint Stock Company). [Electronic resource]. The URL : http : // www . by Gazprombank . ru / upload the / iblock / 482 / GPB _ Infrastructure _ the update -250615.pdf

[2] A. Shumaev, D.E. Morkovkin, V.N. Nezamaykin, I.L. Yurzinova Organizational-economic aspects of management of innovative development of industry // Mechanisation of construction. - 2015. No. 3. - pp. 53-59.

[3] A. Shumaev. Problems of innovative development of Russia // Innovation and Expertise. - 2013. - No. 1. - pp. 190-197.

[4] Shumaev. Development of logistics as an effective management tool // Economist. - 2013. - No. 10. - pp. 29-35.

[5] S. Sandu, N.E. Ryzhenkova, M.Y. Veselovsky, A.Y. Solovyov. Economic aspects of innovation-oriented market economy formation // Life Science Journal. 2014. T. 11. № 12. pp. 242-244.

[6] Shumaev, D. Morkovkin. Import substitution as the strategic direction and innovation-industrial development of the Russian economy // 
RISK: Resources, information, procurement, competition. - 2014. No. 4. - pp. 123-126.

[7] N. Nezamaykin, D. E. Morkovkin. The development of innovation management institutions in the real sector of the Russian economy // Management in social and economic systems: materials of the international scientific-practical conference. May 21, 2015 / red. Y. S. Rudenko, R.M. Bottoms, M. A. Zaitseva [electronic publication]. M .: "MU named after SY Witte ", 2015. - pp. 401-409.

[8] D.E. Morkovkin. The development of cooperation between the state and business in Russia: current state and prospectives // Economy in the industry. - 2016. - № 1. - pp. 4-7. - DOI: 10.1707 / 2072-16632016-1-4-7

[9] D.E. Morkovkin. Challenges and priorities of financing innovative development of the real economy sector // Bulletin of Financial University. - 2015. - № 6 (90). - pp. 39-49.

[10] J.V. Gnezdova, D.V. Kuzin, A.Yu. Manyushis, I.A. Filkevich, L.A. Yunusov. Transformation of innovation infrastructure in the conditions of organizational changes in Russia // International Journal of Economics and Financial Issues. 2016. T. 6. № 2. pp. 82-87.

[11] M.Y. Veselovsky, J.V. Gnezdova, J.A. Romanova, I.V. Kirova, I.I. Idilov. The strategy of a region develovment under the conditions of new actual economic // Mediterranean Journal of Social Sciences. 2015. T. 6. № 5 S2. pp. 310-317.

[12] D.E. Morkovkin, A.Y. Mamychev, N.V. Yakovenko, I.V. Komov, M.V. Derevyagina, O.V. Didenko. Factors and material conditions for space-intensive economic development of region // International Review of Management and Marketing. -2016. - T. 6. - № S1. - pp. 67-72.

[13] Official website of the Center for Economic Research. The URL: http://www.erce.ru / (date of use: 20.08.2017).

[14] M. Shalneva, K. Zabolotskaya. Development of transport infrastructure as the factor of growth of the Russian economy // Financial life. - 2016. - №1. - pp. 12-17. 